\title{
SERPINF2 Gene
}

National Cancer Institute

\section{Source}

National Cancer Institute. SERPINF2 Gene. NCI Thesaurus. Code C129261.

This gene plays a role in the inhibition of serine proteinases. 